\title{
DERIVED CHARACTERISTICS OF THE ROSS ICE SHELF, ANTARCTICA
}

\author{
By R. H. Тномаs* \\ (OAO Corporation, 7500 Greenway Center Drive, Greenbelt, Maryland 20770, U.S.A.) \\ and D. R. MACAYEAL \\ (Geophysical Fluid Dynamics Laboratory, Princeton University, Box 308, Princeton, New \\ Jersey 08540, U.S.A.)
}

\begin{abstract}
Results of the Ross Ice Shelf Geophysical and Glaciological Survey (RIGGS) provide the most complete data set available for any large portion of the polar ice sheets. In this paper, we use the RIGGS data to calculate some of the ice-shelf characteristics. These include steady-state particle trajectories through the ice shelf and the depth of isochronous surfaces, which are of particular importance in choosing a drilling site where ice from the grounded West Antarctic ice sheet is likely to be near the surface. Our estimates for depth to ice originating from the $500 \mathrm{~m}$ elevation contour show good agreement with depths to a glaciochemical transition in four ice cores that is believed to be associated with this elevation. This suggests that, for much of the ice shelf, there have been no dramatic and sustained departures from steady state during the past 1500 to 2500 years. With the RIGGS data and an assumed bottom-melting rate distribution we calculate steady-state temperature profiles at each of the measurement stations. Then, adopting an ice flow law deduced from laboratory experiments and ice-shelf measurements, we obtain an effective flow-law parameter for each of these sites. Using these values, the measured strain-rate field is transformed to an equivalent stress field over the ice shelf. The stresses are determined by the ice-shelf freeboard and by the force field exerted on the ice shelf by its sides and by grounded ice rises, and our analysis yields estimates of these "restraining" forces $F$ for the Ross Ice Shelf. An apparent increase in $F$ very close to the ice front suggests that the ice shelf possesses a narrow seaward fringe of anomalously stiff ice. We suspect that this represents the effects of increased bottom melting rates (and therefore colder and stiffer ice) very close to the ice front. In order to illustrate the role of the restraining forces in controlling ice-shelf behavior, we calculate the strain-rate field for an unrestricted Ross Ice Shelf —one that is detached from its sides and contains no ice rises. Currently the creep-thinning rates for most of the ice shelf is $(0.5-1) \mathrm{m} \mathrm{year}^{-1}$; for an unrestricted ice shelf, they would increase to (1-10) $\mathrm{m} \mathrm{year}^{-1}$, with values up to $60 \mathrm{~m}_{\text {year }}^{-1}$ up-stream of the ice rises.
\end{abstract}

RÉSumÉ. Traits caractéristiques du Ross Ice Shelf en Antarctique. Les résultats du Ross Ice Shelf Geophysical and Glaciological Survey (RIGGS) ont apporté le lot de données le plus complet qui soit disponible sur une grande partie de la calotte glaciaire polaire. Dans cet article, nous utilisons les données du RIGGS pour calculer certaines des caractéristiques de la plateforme de glace. Celles-ci comprennent les trajectoires en ètat d'équilibre des particules à travers la calotte et la profondeur des surfaces isochrone qui sont d'une importance particulière pour choisir un site de forage oủ la glace en provenance de la partie proche du sol de la calotte glaciaire Ouest Antarctique a des chances d'être proche de la surface. Nos estimations pour la profondeur de la glace issue de la ligne de niveau d'altitude $500 \mathrm{~m}$ montrent un bon accord avec les profondeurs d'un niveau de transition glaciochimique trouvée dans quatre carottes de forages glaciaires et que l'on croit liee à cette altitude. Ceci fait penser que, pour une grande part de la plateforme de glace, il n'y a pas eu d'écart important et durable par rapport à la position d'équilibre durant les derniers 1500 à 2500 ans. Grâce aux données du RIGGS et à une hypothèse pour la distribution de la vitesse de fusion au fond du lit nous calculons les profils de température à l'ètat d'équilibre pour chacune des stations de mesure. Par suite, en adoptant une loi d'écoulement de la glace déduite d'expériences de laboratoire et de mesures sur la plateforme de glace, nous obtenons les paramètres effectifs de la loi d'écoulement pour chacun de ces sites. En utilisant ces valeurs le champ des vitesses de déformation mesurées est transformé en un champ équivalent des efforts dans la plateforme de glace. Les efforts sont déterminés par la hauteur émergée de la plateforme et par le champ des forces exercées sur la platforme par ses rives et par l'avancée de la glace au sol, et notre analyse donne les estimations de ces forces

* Present address: California Institute of Technology, Jet Propulsion Laboratory, 4800 Oak Grove Drive, Pasadena, California 91109, U.S.A. 
"résistantes" $F$ pour le Ross Ice Shelf. Une augmentation de la valeur apparente de $F$ auprès de la falaise de glaces flottantes suggère que la plateforme de glace possède une marge étroite au bord de la mer composée de la glace anormalement dure. Nous estimons que celui-ci représente les effets d'une augmentation de la vitesse de fonte audessous de la plateforme (et ensuite que la glace est plus froide et plus dure) auprès de la falaise. Afin d'illustrer l'importance de ces forces pour le contrôle du comportement de la plateforme, nous calculons le champ des vitesses de déformation pour une Ross Ice Shelf qui ne serait retenue par aucune contrainte, c'est-à-dire qui serait détachée de ses rives et ne subirait aucune dome insulaire de glace. En moyenne la vitesse d'amincissement par glissement pour la plus grande partie de la plateforme est de 0,5 à $1 \mathrm{~m}$ par an pour une plateforme sans contraintes, elle atteindrait de 1 à $10 \mathrm{~m} /$ an avec des valeurs de plus de $60 \mathrm{~m} / \mathrm{an}$ à l'amont des domes insulaires de glace.

Zusammenfassung. Abgeleitete Charakteristiken des Ross Ice Shelf, Antarktika. Die Ergebnisse des Ross Ice Shelf Geophysical and Glaciological Survey (RIGGS) stellen de vollständigsten Datensatz dar, der für irgendeinen grösseren Teil des antarktischen Eisschildes verfügbar ist. In dieser Arbeit werden die RIGGS-Daten zur Berechnung einiger Charakteristiken des Schelfeises benutzt. Dazu gehören stationäre Stromlinien durch das Schelfeis und die Tiefe isochroner Flächen, die für die Wahl einer Bohrstelle mit vermutlich oberflächennahem Festeis aus der Westantarktis von besonderer Bedeutung sind. Unsere Abschätzung der Tiefe bis zu Eis, das aus dem $500 \mathrm{~m}$-Niveau stammt, steht in guter Übereinstimmung mit der Tiefe zu einem geochemischen Übergang in vier Eiskernen, der für verbunden mit dieser Höhe gehalten wird. Dies lässt vermuten, dass für einen Grossteil des Schelfeises keine dramatischen und länger anhaltenden Abweichungen vom stationären Zustand während der letzten 1500 bis 2000 Jahre eingetreten sind. Mit den RIGGS-Daten und einer angenommenen Verteilung der Abschmelzrate an der Unterseite wurden stationäre Temperaturprofile an jeder Messtation berechnet. Dies führt unter Einführung eines aus Laborversuchen und Schelfeismessungen hergeleiteten Fliessgesetzes auf einen effektiven Fliessgesetzparameter für jede dieser Stellen. Damit wird das gemessene Deformationsfeld in ein äquivalentes Spannungsfeld über dem Schelfeis transformiert. Die Spannungen werden aus der Höhe des Schelfeises über dem Meeresspiegel und aus dem Kraftfeld, das auf das Eis durch seine seitlichen Begrenzungen und durch Erhebungen infolge Aufsitzens am Untergrund ausgeübt wird, bestimmt; unsere Analyse führt zu Abschätzungen dieser "beschränkenden" Kräfte für das Ross Ice Shelf. Eine scheinbare Zunahme von $F$ sehr nahe der Eisfront lässt annehmen, dass das Schelfeis nahe dem Meer einen Rand von ungewöhnlich steifen Eis besitzt. Wir vermuten, dass sich darin die Wirkung der erhöhten Schmelzraten am Untergrund (die zu kälteren und steiferen Eis führen) sehr nahe an der Eisfront wiederspiegelt. Um den Einfluss dieser Kräfte auf das Verhalten des Schelfeises zu beleuchten, wird das Deformationsfeld für ein enbehindertes Ross Ice Shelf berechnet-eines, das von seinem seitlichen Bergrenzungen losgelöst ist und keine Eiserhebungen aufweist. Derzeit beträgt die Ausdünnung durch Krieschen für den Grossteil des Schelfeises 0.5-1 m pro Jahr: für ein unbehindertes Schelfeis würde sie auf $1-10 \mathrm{~m}$ pro Jahr mit Werten bis zu $60 \mathrm{~m}$ pro Jahr hinter den Eiserhebungen ansteigen.

\section{INTRODUCTION}

The Ross Ice Shelf is now the most thoroughly studied major portion of the Antarctic ice sheet. There are measurements of ice thickness, water depth, snow accumulation rates, surface isotope delta values, ice velocity, strain-rates, and $10 \mathrm{~m}$ temperatures at stations forming a $55 \mathrm{~km}$ grid over almost the entire ice shelf (Bentley and others, 1979; Clausen and others, 1979; Robertson and others, 1982; Thomas and others, in press). Here we use these data to calculate:

(i) Steady-state particle paths along selected flow lines, isochronous surfaces, and the depth to the transition between ice-shelf derived ice and inland ice.

(ii) Steady-state temperature/depth profiles at 150 of the RIGGS stations.

(iii) Effective ice-hardness parameters at the same stations.

(iv) The back pressure acting on the ice shelf because of shear at the margins and compression up-stream of ice rises.

(v) Equivalent vertical strain-rates for a Ross Ice Shelf that is detached from its sides and which contains no ice rises. 


\section{PARTICLE PATHS}

After a snow particle has fallen on the ice shelf, it moves seaward with the ice shelf, and it moves downward with respect to the ice-shelf surface at a speed determined by the local values of snow-accumulation rate $\dot{A}$ and vertical creep rate $\dot{\varepsilon}$. Generally, its most rapid descent is through the low-density upper layers of the ice shelf, where downward movement in one year is approximately the local annual accumulation expressed as a thickness of firn with density appropriate to the particle's depth $z$. At greater depths, the downward velocity is $\dot{A}+z \dot{\varepsilon}$, where $\dot{A}$ and $\dot{\varepsilon}$ are values appropriate to the current location of the particle, and $\dot{A}$ is expressed as a thickness of solid ice per unit time. Generally, $\dot{\varepsilon}$ is negative, so that the downward velocity decreases until the particle trajectory is parallel to the ice-shelf surface. Thereafter, for approximately constant accumulation rates, the particle rises in areas of large strain-rate, and descends in areas of low strain-rate.

Particle paths can be calculated, either analytically by making simplifying assumptions or, more accurately by summing the forward and downward motions of the particle as it moves through differing regimes of ice velocity, accumulation rates, and strain-rates. However, it should be stressed that, unless we can describe how these parameters have varied with time, the calculated trajectories apply to a steady-state situation in which ice velocities, accumulation rates, and strain-rates have been invariant with time, and we can use current measurements to describe them. Although this is never achieved in a real ice sheet, departures from this state may be small, and calculated steady-state particle paths provide a base-line estimate of ice chronology at depth. This can be compared with drill-hole observations in order to detect major departures

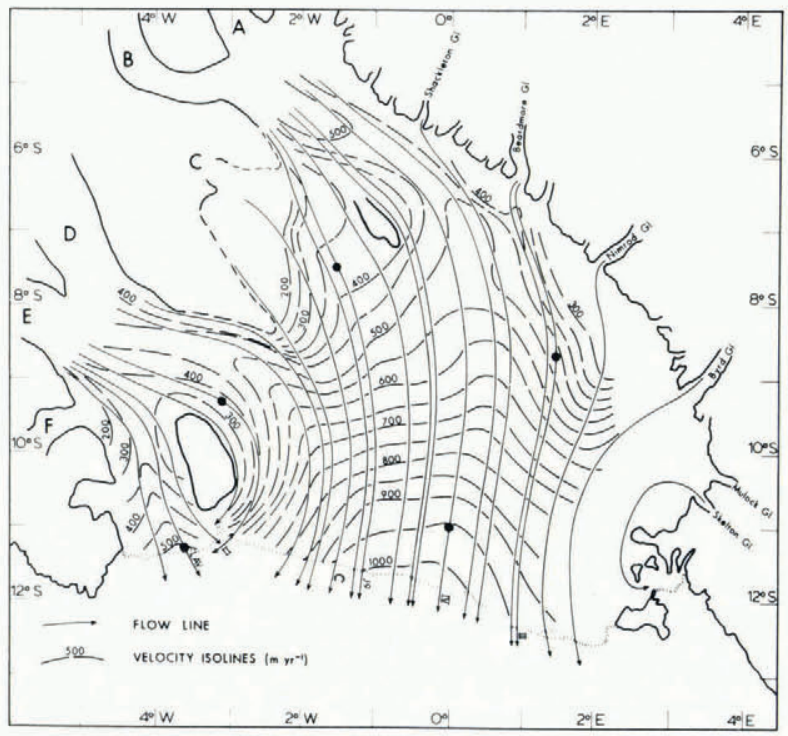

Fig. 1. Velocity field of ice flow in the Ross Ice Shelf. The labeled flow lines are the ones that pass through three of the RIGGS camps (II to IV), the RISP bore hole at J9, and Little America V (LAV); the solid circles mark the positions of these stations. Velocity isolines are marked in units of $m$ year ${ }^{-1}$. The bold letters $A-F$ mark the positions of ice streams that drain the West Antarctic ice sheet. The coordinates on this and the other maps are grid coordinates. In this system, one degree is approximately $111 \mathrm{~km}$ (60 nautical miles), and the north/south direction is parallel to the $180^{\circ}$ meridian, with grid north towards the South Pole. 
from steady state. To calculate steady-state particle paths for the flow lines across the Ross Ice Shelf shown in Figure 1, we used the numerical technique described by Thomas $(1973|\mathrm{c}|)$ which takes account of density variations with depth and their effect on the downward motion of snow particles. We adopted a composite density/depth variation that provides a good approximation to the measured densities at Little America V (LAV), and at J9 (Gow, 1963; personal communication from C. C. Langway, Jr).

Particle paths for six of the flow lines are shown in Figure 2. Lack of data from inland of the grounding line restricted our calculations to the trajectories of snow particles that fell on the ice shelf. Thus, the origins of the flow lines in Figure 2 are some tens of kilometers to seaward of the grounding line. For the flow lines corresponding to fast ice streams and glaciers, the time taken for ice to travel from the grounding line to the flow-line origin is small, and the estimated depths should provide a good approximation to the transition depth below which ice is from inland of the grounding line. However, ice velocities and strain-rates are very low at the start of the two flow lines down-stream from ice stream C (in Fig. 1), and the transition depth for the first 100
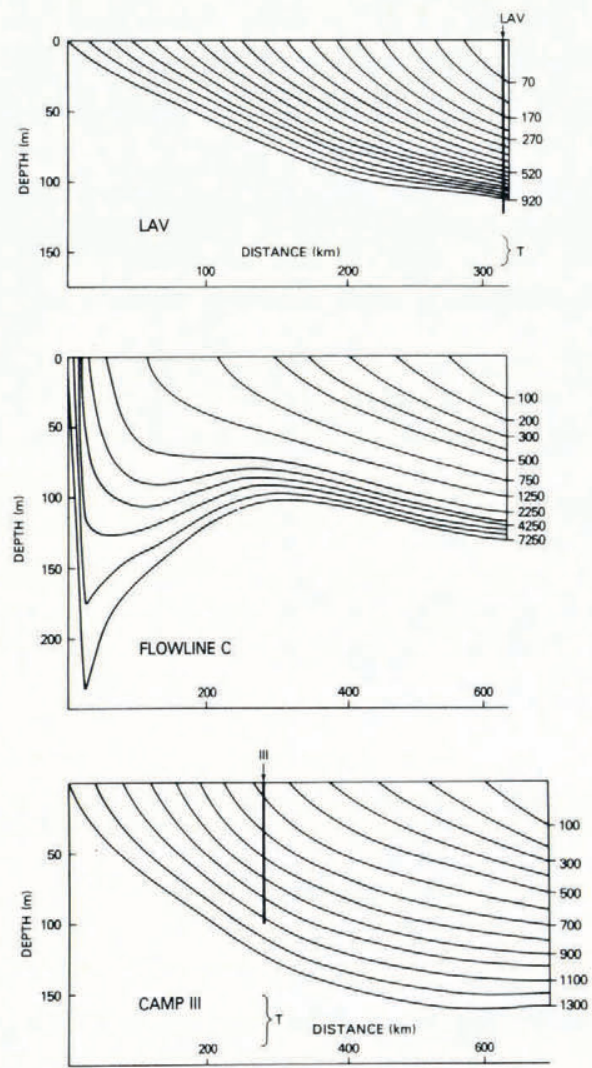
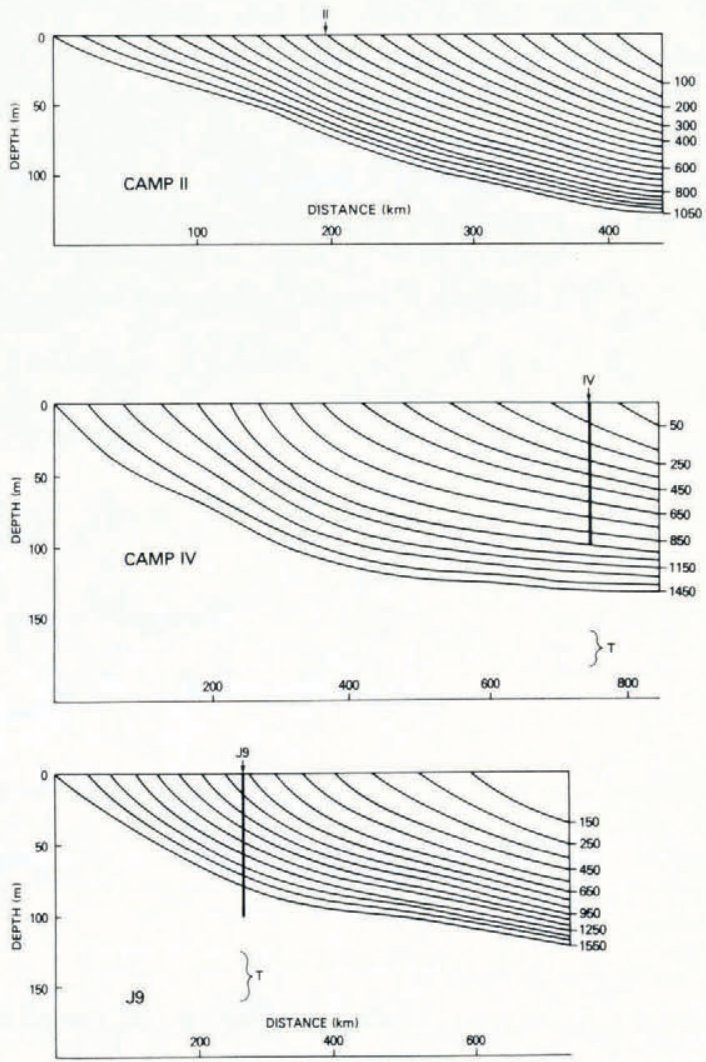

Fig. 2. Steady-state particle paths along six of the flow lines shown in Figure 1. The positions of stations are marked on the diagrams and, where appropriate, drill holes are indicated by heavy, vertical lines. All of the particle paths terminate at the seaward ice front, and their ages in years at this point are listed on the diagrams. The bracketed regions marked $T$ indicate our estimates of the depth of ice that originated at the $500 \mathrm{~m}$ elevation contour on the inland ice sheet. 
to $200 \mathrm{~km}$ may be considerably deeper than for the oldest of the calculated particle paths. Further seaward, our estimates should provide a good approximation because the transition depth is then mainly determined by increased values of local strain-rate rather than by up-stream accumulation history.

Errors in our calculated particle trajectories arise from two distinct sources. Inadequacy of the steady-state assumption results in differences between calculated and actual particle paths. However, one of the reasons for calculating particle paths is to identify these differences and use them as indicators of non-steady-state behavior. Consequently, we can restrict a consideration of errors to those arising from errors in the observations of snow accumulation rates, ice velocity, and strain-rates.

The RIGGS data were obtained at stations forming a $55 \mathrm{~km}$ grid over the entire ice shelf. The observations, and associated errors, are discussed at some length by Thomas and others (in press). In general, errors are small and probably random. We interpolated between the ice-shelf grid points to obtain data at $20 \mathrm{~km}$ intervals along each flow line shown in Figure 1. These interpolated data were then used for the particle-path calculations. Assuming that errors in the data are approximately constant along each $20 \mathrm{~km}$ segment, the corresponding error in snowparticle depth increments within the segment is $\pm(1$ to 1.5$) \mathrm{m}$ for most of the ice shelf. If this error is independent of errors in other segments, then the maximum error in snow particle depth for an $800 \mathrm{~km}$ flow line is $\pm(6$ to 10$) \mathrm{m}$. These small errors in the steady-state particle trajectories apply to all the flow lines in Figure 1 except the two that are down-stream from ice stream C. They permit comparison with actual ice-core chronologies in order to reveal nonsteady-state behaviour. The residence time for a snow particle in the first $20 \mathrm{~km}$ segment of flow line C (Fig. 2) is approximately 3000 years. The error in calculated particle depths within this segment may be as high as $\pm 100 \mathrm{~m}$. However, errors rapidly diminish to seaward as the ice velocity increases; only the trajectories of particles originating within the first 50 to $100 \mathrm{~km}$ of flow line $\mathrm{C}$ are likely to include serious errors.

\section{TRANSITION DEPTHS}

Figure 3 shows depth contours for the oldest particles for which we have calculated trajectories; they represent the minimum depth to the steady-state transition surface marking the top of the ice from inland of the grounding line. There is a notable area down-stream from ice stream $\mathrm{C}$ where the transition depth exceeds $400 \mathrm{~m}$. This is in an area of low velocity and low creep rates and its calculated position is rather sensitive to the position of the flow-line origin. In our case, the flow line passing through this area originates to seaward of the grounding line in an area of low velocities. For a flow line originating at the grounding line the transition depth would be greatest in an area of zero vertical creep c. $50 \mathrm{~km}$ up-stream from the position shown in Figure 3. This would coincide almost exactly with a bulge in ice-shelf thickness (Bentley and others, 1979) that is probably caused by the same combination of low velocities and strain-rates. The coincidence of these two features suggests that velocities and strain-rates in this area have remained unchanged for a period long enough for the thickness bulge to form.

For most of the ice shelf the transition depth is less than $150 \mathrm{~m}$ and, in many areas, it would be possible to sample inland ice with a $100 \mathrm{~m}$ drill. We then would have the problem of distinguishing it from ice-shelf derived ice. Herron and Langway (1979) have suggested that the sodium content of the ice may provide a criterion for distinguishing between East Antarctic ice 


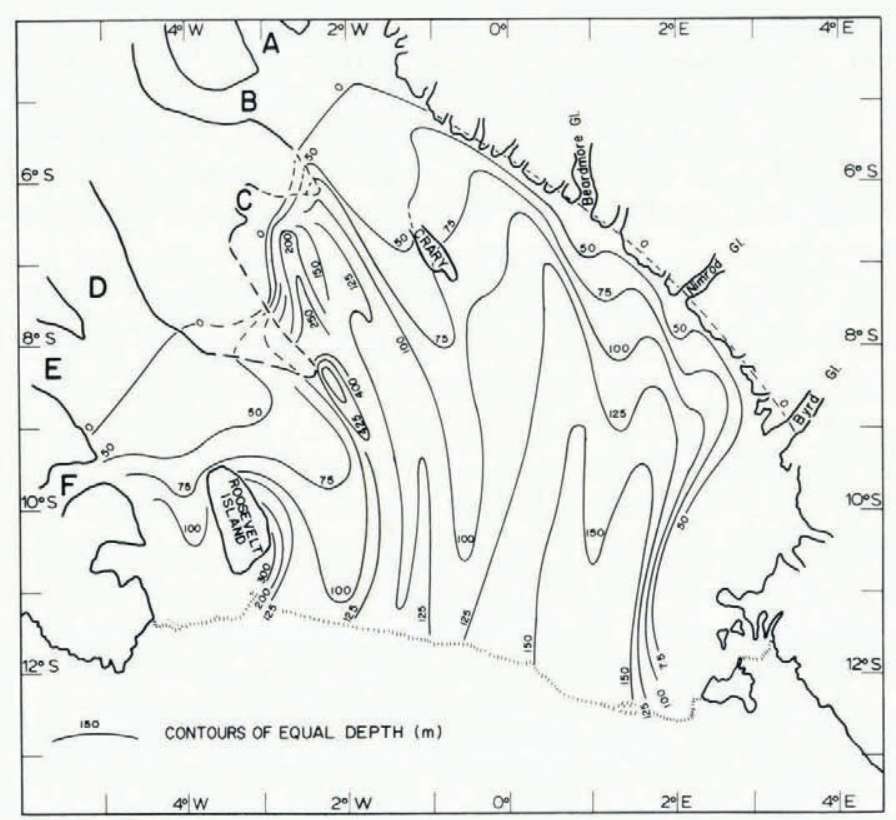

Fig. 3. The depth in meters of ice that originated at the 0 contour shown. The 0 contour marks the inland limit of our data coverage. However, for most of the ice shelf these depths are only slightly less than the depths to the transition between ice-shelf derived ice and inland ice.

(sodium concentration of $\left.10^{-8}\right)$. West Antarctic ice $\left(3 \times 10^{-8}\right)$, and ice-shelf derived ice $\left(>3 \times 10^{-8}\right)$. However, the chemical transition from ice shelf to inland ice sheet probably occurs near the $500 \mathrm{~m}$ elevation contour which, for the West Antarctic ice streams, is up to $200 \mathrm{~km}$ inland of the grounding line. Unfortunately, we do not have sufficient data to calculate particle paths from the $500 \mathrm{~m}$ contour. Nevertheless, we have included approximate estimates of the depth of the " $500 \mathrm{~m}$ transition", $\mathrm{T}$ in Figure 2, at the stations where holes were drilled. These were calculated by assuming that, at the $500 \mathrm{~m}$ contour for each of the four flow-lines (LAV J9, III, and IV in Fig. 1), ice velocity is $100 \mathrm{~m}$ year $^{-1}$, accumulation rate is $0.15 \mathrm{~m}$ of ice year ${ }^{-1}$, and vertical strain-rate is $10^{-3}$ year $^{-1}$. Data at intermediate points were obtained by linearly interpolating between these assumed values and the measured values on the ice shelf. The depth range identified by $\mathrm{T}$ in Figure 2 allows for large errors in the assumed values.

At LAV Herron and Langway (1979) found the "glaciochemical transition" to be at a depth of $155 \mathrm{~m}$, which is in very good agreement with our estimate for the depth of the " $500 \mathrm{~m}$ transition". At J9, Herron and Langway estimate the glaciochemical transition to be approximately $130 \mathrm{~m}$ beneath the surface, which is at the shallow end of our estimated range for T. However, at this station, the Herron and Langway estimate was obtained by extrapolating their observations using a particle-path calculation. Their assumed values of velocity and strainrate for the region up-stream of the grounding line differ from ours; in particular, they assume a constant velocity of $400 \mathrm{~m} \mathrm{year}^{-1}$ from the $500 \mathrm{~m}$ contour to the grounding line. With lower ice velocities their estimated depth for the glaciochemical transition would show better agreement with our estimate for $\mathrm{T}$.

At Camps III and IV ice cores were collected to a depth of only $100 \mathrm{~m}$. The sodium 
concentration within these cores shows a decreasing trend at greater depths (Watroba, 1980), and M. M. Herron (personal communication, 1981) estimates the minimum depth of the glaciochemical transition to be c. $150 \mathrm{~m}$ at Camp III and c. $130 \mathrm{~m}$ at Camp IV. Herron's Camp III estimate is at the shallow end of our estimate for $\mathrm{T}$, and the difference between our estimates is almost entirely due to our different assumed velocities for Beardmore Glacier. At Camp IV, however, we estimate $\mathrm{T}$ to be at $170 \mathrm{~m}$, compared to Herron's estimate of $130 \mathrm{~m}$ which, in our reconstruction, is the depth of ice from the grounding line. Part of this difference is undoubtedly due to the different values of velocity and strain-rate that were assumed up-stream of the grounding line. But in this case there is probably a residual difference which may represent nonsteady-state history of the ice shelf and ice stream A, or it may indicate that the deeper ice came from East Antarctica (with low impurity levels) via ice stream A or Reedy Glacier, rather than from West Antarctica as assumed by Herron. Field evidence suggests that, currently, the ice shelf is not in steady state, with apparent thickening in the grid north-west (Thomas and Bentley, 1978) and many apparent "transients in the dynamic system" (Bentley and others, 1979). However, good agreement between our estimates of the steady-state " $500 \mathrm{~m}$ transition depth" and the independent estimates of the glaciochemical-transition depth indicates that there have been no dramatic departures from steady state during the last 1500 to 2500 years. Consequently, either the departures from steady state are merely random perturbations to a long-term steady-state condition, or sustained imbalance has been too small to have markedly shifted the transition depth. Here we should stress that the uncertainties in our estimates in transition depth could mask a measure of sustained ice-shelf imbalance, but probably not one of large magnitude. Moreover, the four available cores do not provide information on the behavior of ice stream C, which is currently very slowly moving, but which probably was far more active in the past (Rose, 1979; Thomas and others, in press). Mapping of the transition depth in $200 \mathrm{~m}$ core holes, and surface measurements on the West Antarctic ice streams would significantly reduce these uncertainties, and would provide much-needed information on the history of the West Antarctic ice sheet.

\section{ISOCHRONOUS SURFACE}

Figures 4 and 5 show the steady-state ages of ice particles at depths of $50 \mathrm{~m}$ and $100 \mathrm{~m}$. At $50 \mathrm{~m}$ depth the ice is between 150 and 650 years old. Its age strongly reflects local rates of snow accumulation and creep; the ice is youngest in areas of high accumulation and low strain-rates. Conversely, the oldest ice is in regions of high creep-thinning rate (immediately grid west of Crary Ice Rise), and/or low accumulation rates (down-stream from ice stream C).

At $100 \mathrm{~m}$ depth the thinning rate becomes the dominant influence. Where this is high, such as down-stream from ice-stream C, very old ice lies at comparatively shallow depths. Figure 2 includes particle paths for a flow line (C) that passes through an area of low velocity and high strain-rates, so that there is a long residence time in the zone of rapid creep thinning. This has allowed 6000 year old ice to rise to within $100 \mathrm{~m}$ of the surface. By contrast, for most of the ice shelf, the $100 \mathrm{~m}$ ice is 500 to 1500 years old. From comparison of these steady-state ages with ice-core chronology at various positions on the ice shelf, it would be possible to reconstruct the non-steady-state history of the ice shelf. It would not be necessary to obtain absolute ages of icecore samples, since chronological markers, such as layers of volcanic ash, could be used to calibrate the cores. It may also be possible to reconstruct actual isochrones from internal layers revealed by radio echo-sounding. 


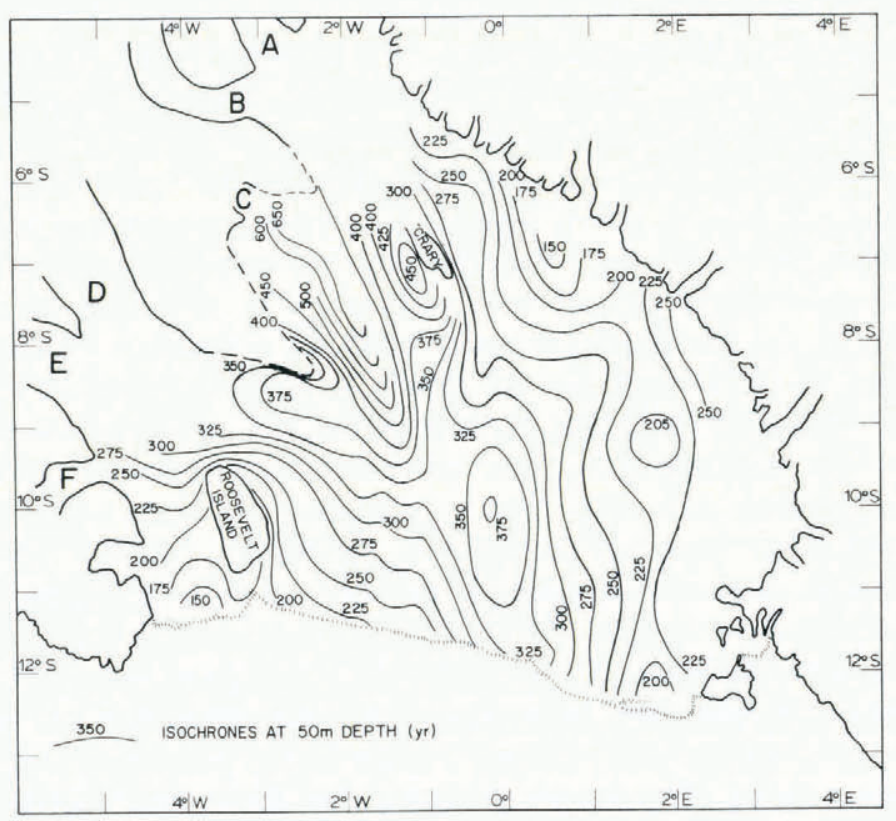

Fig.4. The age in years of ice at a depth of $50 \mathrm{~m}$.

\section{STEADY-STATE TEMPERATURES}

The temperature/depth profile at any point on the ice shelf is influenced, to a greater or lesser extent, by conditions up-stream from that point. If ice thicknesses, surface temperatures, snow accumulation rates, bottom-melting rates, and strain-rates were the same at all points on the ice shelf, then this influence would be minimal; it would not be completely absent because conditions on the inland ice sheet differ from those on the ice shelf, and regions of severe crevassing on the ice shelf, particularly bottom-crevassing, possess a distinctive thermal regime. A rigorous analysis of heat flow would require a three-dimensional numerical calculation, and this would be extremely time consuming. A simpler approach is to obtain temperature/depth profiles, along a single flow line, from a one-dimensional time-dependent analysis for a vertical ice column which is allowed to move along the flow line and experience all appropriate changes in boundary conditions as it moves from the grounding line to the ice front (MacAyeal, unpublished). The temperature profile at any position along the flow line is then obtained from the time-dependent solution for the column at that position. The solution includes the effects of local boundary conditions and the thermal memory of different conditions up-stream. Moreover, it is simple to allow for conditions that change with time. Heat conduction in the horizontal direction cannot be treated by this method, but the resulting errors are negligible because horizontal temperature gradients are generally several orders of magnitude smaller than those in the vertical direction. Although this approach is also rather time consuming, it is essential if measured profiles are to be used as indicators of boundary conditions, such as bottom-melting rates. Generally, these are not known, so numerous bottom-melting scenarios must be tested to indicate which gives temperatures that best fit the observations. Measurements from the $\mathbf{J} 9$ drill hole (Fig. 1) have been analyzed in this way (MacAyeal and Thomas, 1979) to show that the observed temperature 


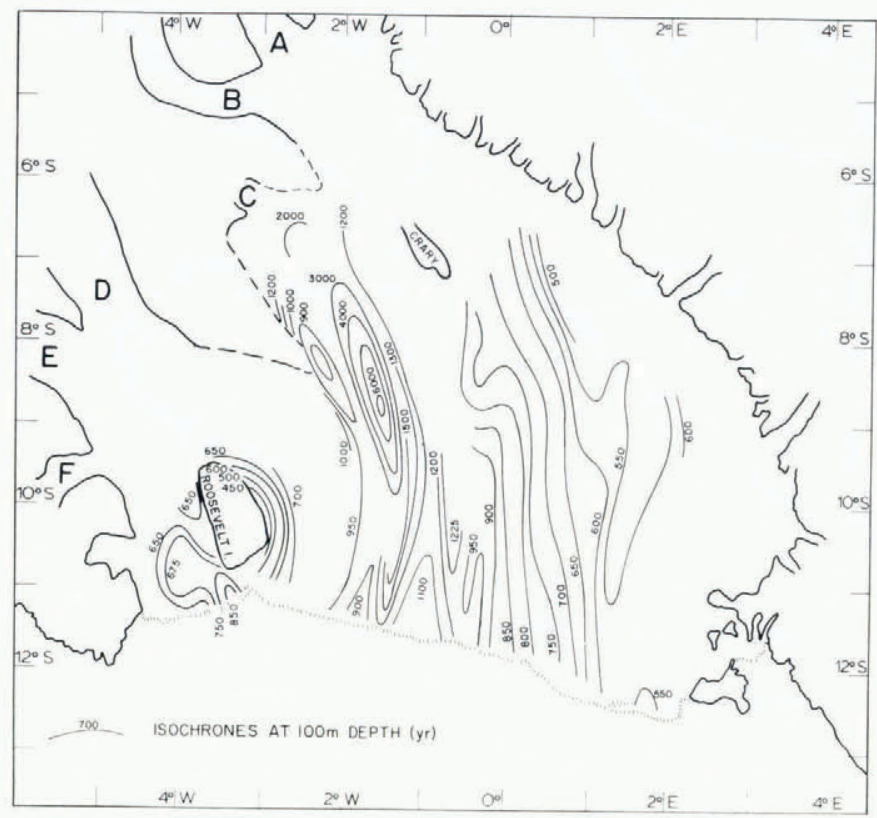

Fig. 5. The age in years of ice at a depth of $100 \mathrm{~m}$.

profile is compatible with a low rate of basal freezing for some distance up-stream from the drill hole. which is consistent with the $6 \mathrm{~m}$ of sea ice at the bottom of the $\mathrm{J} 9$ drill hole (Zotikov and others, 1980).

For most of the ice shelf, there is no indication of what the bottom-melting rates are, and we can only make an arbitrary estimate of them. Because this estimate has a powerful influence on the calculated temperature profiles, and we have few temperature measurements with which to tune the estimate, we have further simplified the heat-flow analysis. At 150 RIGGS stations, and at LAV, we calculated steady-state temperature/depth profiles using a one-dimensional finiteelement analysis of thermal equilibrium in a vertical ice column having boundary conditions appropriate to the relevant station. The calculations included the effects of density variations in the upper layers of ice shelf, but not of the thermal memory of up-stream conditions. Strain heating in the ice shelf is very small, and we neglected it. Bottom-melting rates were assumed to be $1 \mathrm{~m}$ of ice year ${ }^{-1}$ at the ice front, decreasing linearly to zero $250 \mathrm{~km}$ inland. Temperature profiles were obtained for the assumed bottom-melting rate, and for both $0.1 \mathrm{~m}_{\text {year }}^{-1}$ more, and $0.1 \mathrm{~m}$ year ${ }^{-1}$ less bottom melting.

Four examples of the resulting temperature profiles are shown in Figure 6: at LAV, J9, Camp III, and Camp IV. Temperatures were also measured in drill holes at these sites (Crary, 1961: Clough and Hansen, 1979; personal communication from C. C. Langway, Jr, 1978), and they are included in Figure 6. The calculated profile at J9 is in good agreement with observation. Better agreement would be obtained with a bottom-melting rate of $c .5 \mathrm{~cm}$ year ${ }^{-1}$, but when allowance is made for the thermal memory of up-stream conditions, excellent agreement with observation is obtained for basal freezing of $c .1 \mathrm{~cm}_{\text {year }}^{-1}$ (MacAyeal and Thomas, 1979). This gives an indication of the degree to which thermal memory influences the temperatures when 

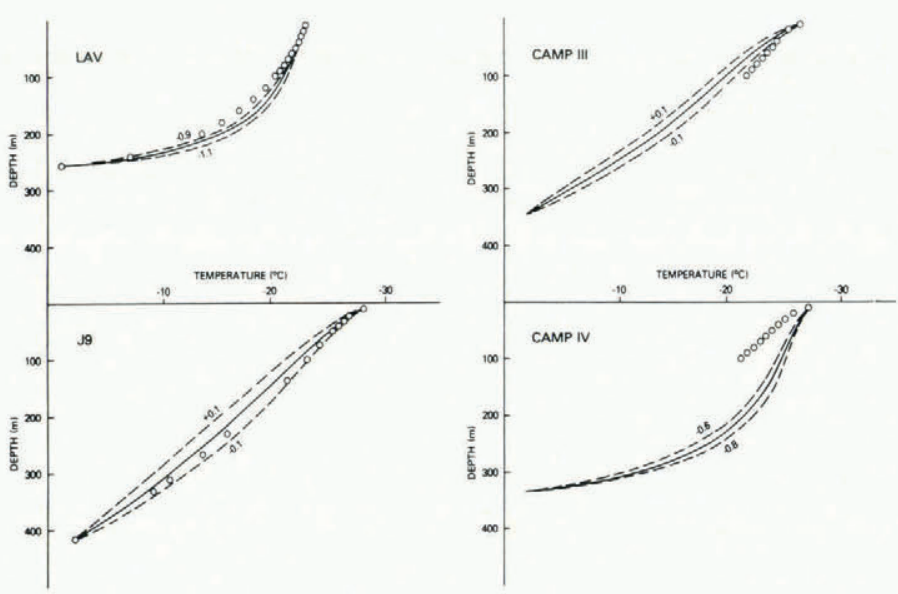

Fig. 6. Calculated steady-state temperature/depth profiles at four stations on the Ross Ice Shelf. Profiles are calculated for an assumed bottom-melting rate $\pm 0.1 \mathrm{~m}^{\text {ice }}$ year ${ }^{-1}$; the limiting values are included on the plots. The hollow circles are temperatures that were measured in drill holes at the stations.

up-stream conditions are comparatively uniform. Marked changes in either melting rate or accumulation rate along the flow line would result in a more pronounced thermal-memory effect. Also a major thermal perturbation up-stream from the station could have a large influence. This may explain the wide difference between the measured and calculated temperatures at Camp IV. where the observed temperatures are consistent with a bottom-melting rate of only $5 \mathrm{~cm} \mathrm{year}^{-1}$, compared to our assumed value of $70 \mathrm{~cm}_{\text {year }}{ }^{-1}$. There are large rifts in the ice shelf within tens of kilometers of this station, and there are large bottom crevasses within a few kilometers. Features such as these may have warmed the ice-shelf interior at Camp IV. However, this is unlikely to explain all of the very large difference, and we suspect that basal melting in this area is considerably less pronounced than we have assumed.

At LAV, our assumed $1 \mathrm{~m}_{\text {year }}{ }^{-1}$ basal melting gives too cold a temperature profile. The observed temperatures are consistent with $0.7 \mathrm{~m} \mathrm{year}^{-1}$ basal melting, which is close to the value obtained by Crary (1961) using a similar analysis. The observations at Camp III, where we assumed zero basal melt, suggest that there is melting of c. $20 \mathrm{~cm} \mathrm{year}^{-1}$. Some of the difference between observed and calculated temperature profiles is probably due to up-stream conditions of greater ice thickness and snow accumulation rate. However, it appears likely that there is bottom melting of perhaps $10 \mathrm{~cm}_{\text {year }}^{-1}$ at Camp III. Consequently, it is clear that our simple assumed bottom-melting scenario is only a rather poor first approximation. A melting rate of $c .0 .7 \mathrm{~m}$ year ${ }^{-1}$ near the ice front decreasing to near zero $100 \mathrm{~km}$ inland may be an improvement. Very close to the ice front, melt rates probably show a rapid increase due to localized heat influx by tidal pumping.

\section{ICE-FLOW PROPERTIES}

The flow law for ice can be written

$$
\dot{\varepsilon}_{i j}=\frac{\tau^{n-1}}{B^{n}} \sigma_{i j}^{\prime}
$$


where $i, j=x, y, z, \dot{\varepsilon}$ is strain-rate, $\sigma^{\prime}$ is the stress deviator; $\tau$ is an "effective shear stress" defined in terms of all the stress-deviator components so that it is independent of the chosen axis direction; $B$ is a hardness parameter determined by temperature, ice fabric, grain-size, etc.; $n$ may be a function of stress, but available data suggest that $n=3$ is a good approximation for glaciological purposes. Laboratory experiments, reviewed by Barnes and others (1971), indicate that the temperature dependence of $B$ can be expressed by the Arrhenius relationship

$$
B(\theta)=B_{0} \exp \{Q / n R T\}
$$

where $Q$ is the activation energy for creep, $R$ is the gas constant, and $T$ is absolute temperature. At low temperatures $Q \approx 80 \mathrm{~kJ} \mathrm{~mol}^{-1}$, but at temperatures greater than $c .260 \mathrm{~K}$, ice contains minute filets of liquid water and it softens appreciably, so that $Q$ increases to $c .120 \mathrm{~kJ} \mathrm{~mol}^{-1}$. Equation (2), with $n=3$, provides a good fit to the laboratory measurements and to ice-shelf observations (Thomas, 1973[a]) if we set $B_{0}=625 \mathrm{~N} \mathrm{~m}^{-2} \mathrm{~s}^{1 / 3}$ and $Q=80 \mathrm{~kJ} \mathrm{~mol}^{-1}$ for $T \leqslant 260 \mathrm{~K} ; B_{0}=1.3 \mathrm{~N} \mathrm{~m}^{-2} \mathrm{~s}^{1 / 3}$ and $Q=120 \mathrm{~kJ} \mathrm{~mol}^{-1}$ for $\theta>260 \mathrm{~K}$.

There are no conclusive data indicating that ice-shelf fabric or grain-size strongly influence the value of $B$, and we have assumed that their influence is negligible. However, we have attempted to take account of the low density (and presumably softer) layers of firn, by assuming that the value of $B$ at depth $z$ is given by:

$$
B(z)=B(T)\left\{\frac{\rho(z)-\rho(0)}{\rho_{\mathrm{i}}-\rho(0)}\right\}
$$

where $\rho(z)$ is the firn density at depth $z$, and $\rho_{\mathrm{i}}=$ the density of solid ice. Because ice-shelf

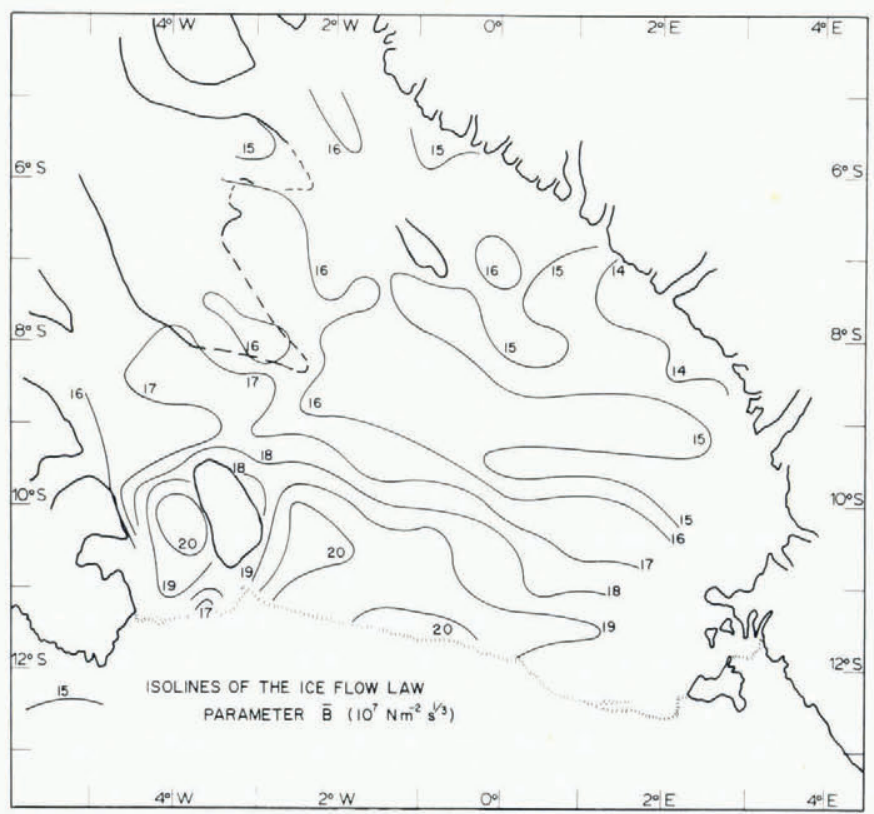

Fig. 7. The ice flow-law parameter in units of $10^{7} \mathrm{Nm}^{-2} \mathrm{~s}^{1 / 3}$ averaged over ice-shelf thickness $(\bar{B})$ for calculated temperature/depth profiles on the Ross Ice Shelf. The assumed temperature dependence of $B$ is given in the text. 
velocities are independent of depth, strain-rates at any location are determined by the value of $B$ averaged over depth $(\bar{B})$ at that location (Weertman, 1957). Using Equations (2) and (3) with the calculated temperature profiles from the last section, we obtained values of $\bar{B}$ at 150 stations on the ice shelf (Figure 7). A range of bottom-melting rates within $\pm 0.1 \mathrm{~m} \mathrm{year}^{-1}$ of the assumed values produces changes in $\bar{B}$ of between \pm 4 and $\pm 15 \mathrm{MN} \mathrm{m}^{-2} \mathrm{~s}^{1 / 3}$.

The range in values of $\bar{B}$ across the ice shelf is from 140 to $200 \mathrm{MN} \mathrm{m}^{-2} \mathrm{~s}^{1 / 3}$. This represents an approximately threefold variation in the strain-rate response to a given stress. The general trend is for $\bar{B}$ to increase to seaward, where high rates of snow accumulation and assumed bottom melting reduce the average ice-shelf temperatures. We stress that these estimates can be regarded only as a first approximation, since there are sure to be errors in the assumed bottommelt rates and in the assumed temperature dependence of $B$. Comparison of the calculated and observed temperatures (Figure 6) indicates that calculated temperatures at $\mathrm{J} 9$ are approximately correct, but at LAV they are slightly too cold, giving too high a value of $\bar{B}$ by $c .10 \%$; at Camp III they are slightly too warm, giving too low a value of $\bar{B}$ by c. $15 \%$, and at Camp IV they are significantly too cold, giving a value of $\bar{B}$ that is c. $25 \%$ too high. However, we have made no attempt to correct our estimates of $\bar{B}$ for the observed errors in our calculated temperatures, since we cannot determine whether conditions at Camps III and IV are typical of the surrounding ice shelf.

\section{FORCES RESTRICTING ICE-SHELF SPREADING}

Floating icebergs and ice shelves spread outwards under the influence of their own weight, and there is a simple relationship between spreading rate $\dot{\varepsilon}$ and ice thickness $H$ (Weertman, 1957).

$$
\dot{\varepsilon}=K\left\{\rho_{\mathrm{i}} g \Delta \rho H\right\}^{n}
$$

where $\rho_{\mathrm{i}}$ is the ice-shelf density (assumed to be independent of depth), $\Delta \rho=\left(1-\rho_{\mathrm{i}} / \rho_{\mathrm{w}}\right)$ with $\rho_{\mathrm{w}}$ the density of sea-water, $K$ is a function of $\bar{B}$ and the ratio between the components of the strainrate tensor, and $n$ is the exponent in Glen's ice flow law, Equation (1). For embayed ice shelves that contain ice rises, there is a back pressure $P$ which reduces the rate of spreading in the direction of movement $\left(\dot{\varepsilon}_{x}\right)$, and Equation (4) becomes

$$
\dot{\varepsilon}_{x}=K\left\{\rho_{\mathrm{i}} g \Delta \rho H-2 P\right\}^{n} .
$$

The Ross Ice Shelf measurements provide all the components of this equation except $n$. With the assumption that $n=3$ and that values of $\bar{B}$ can be calculated as described earlier, we have solved Equation (5) at 150 stations on the Ross Ice Shelf for $F(=P H)$, the force opposing movement which acts on a unit width of ice shelf. The results are shown in Figure 8 as contours of equal $F$. The effect on $\bar{B}$ of varying the bottom-melting rate by $\pm 0.1 \mathrm{~m}^{-1}$ year $^{-1}$ change $F$ by 1 to c. $3 \mathrm{MN} \mathrm{m}^{-1}$. If bottom-melting rates are less than we assumed, with an ice-front value of c. $0.7 \mathrm{~m} \mathrm{year}^{-1}$ decreasing to near zero $100 \mathrm{~km}$ inland, then our estimates of $F$ within the $250 \mathrm{~km}$ nearest the ice front are too low by an average of $c .3 \mathrm{MN} \mathrm{m}^{-1}$. In general, $F$ is sufficient to almost balance the weight forces that induce spreading. This means that $\dot{\varepsilon}_{x}$ is generally rather small, even where the ice shelf is very thick. There is a trend for seaward reduction in $F$, with the $10 \mathrm{MN} \mathrm{m}^{-1}$ contour 50 to $100 \mathrm{~km}$ inland from the ice front. Extrapolation of the decreasing trend in $F$ puts the zero contour close to the ice front, suggesting that our estimated values of $\bar{B}$ are not grossly in error. 


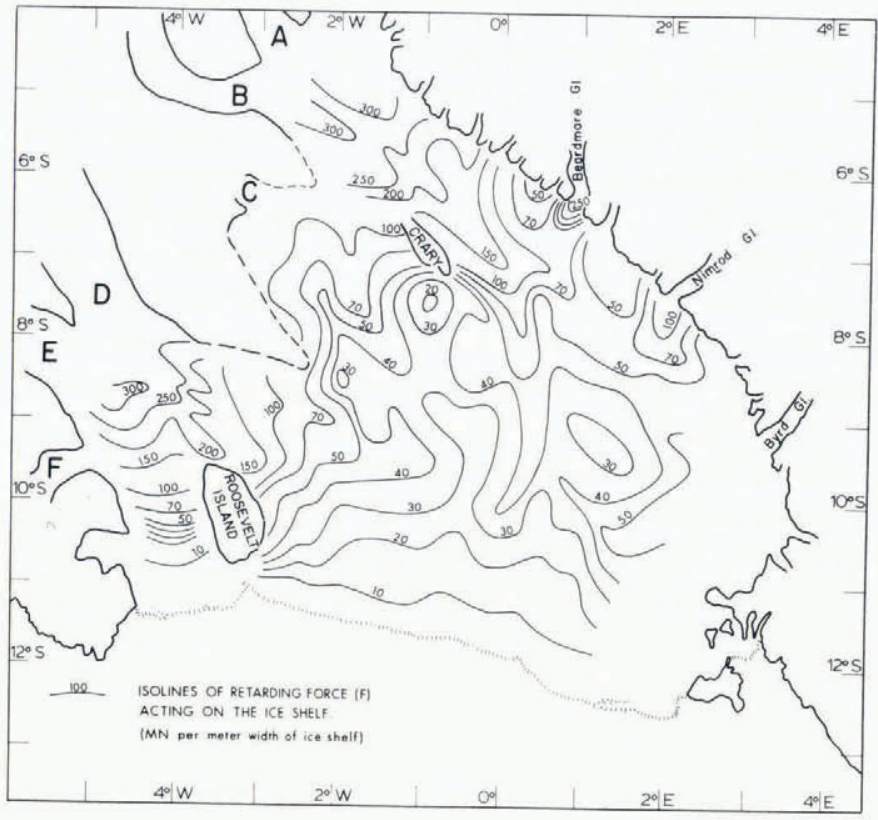

Fig. 8. The retarding force in $M N$ per meter width of ice shelf acting on the Ross Ice Shelf due to effects such as shearing past margins, and compression up-stream of ice rises and in the mouths of ice streams and glaciers.

Creep-rate measurements within a few kilometers of the ice front (Thomas and others, in press) reveal that the direction of maximum extension is generally parallel to the ice front, with tensile creep rates close to zero in the direction of movement. We suspect that this is because the ice front tends to increase in length to conform to the transverse variation in velocity, just as the fabric of a balloon increases in area when it is inflated. This is achieved by tensile strain along the ice front, and a corresponding reduction in tensile creep perpendicular to the ice front. Our estimates of $F$ take account of all components of the strain-rate tensor, and they should not be affected by the locally increased lateral strain. However, most of the stations near the ice front have values of $F$ in the range 5 to $10 \mathrm{MN} \mathrm{m}^{-1}$, larger than the values for stations $50 \mathrm{~km}$ inland. Errors in our estimates are determined mainly by errors in measured ice thickness and assumed ice-flow parameters; strain-rate errors have a very small influence. As $F \rightarrow 0$ ice-thickness errors have a particularly large proportional effect. However, the pattern of isolines in Figure 8 indicates consistency between data points even near the ice front where $F \rightarrow 0$. This suggests that random errors in the data are small. The high values of $F$ near the ice front could result from ice thickness measurements that are systematically too large (by c. $20 \mathrm{~m}$ ). Alternatively, there could be a seaward fringe of ice shelf, perhaps $10 \mathrm{~km}$ wide, with values of $B$ that are $10 \% \rightarrow 20 \%$ larger than we assumed. This is precisely what we would expect if the ice shelf in this fringe is colder because of locally high melting rates. Data from the Brunt Ice Shelf indicate that basal melt rates do increase significantly within a few kilometers of the ice front (Thomas, 1973[c]), and this is consistent with anticipated localized heat influx due to tidal pumping.

Figure 8 displays several interesting features. Of major significance are the very high values of $F$ up-stream of the two ice rises: Roosevelt Island and Crary Ice Rise. Here $F$ increases to approximately double the anticipated value for an ice shelf without ice rises, highlighting the 
influence of ice rises on ice-shelf thickness up-stream, and therefore on the position of the grounding line between ice shelf and inland ice sheet. Large values of $F$ are also found at the mouths of the Beardmore and Nimrod Glaciers indicating the effects of fast-moving ice pushing into the ice shelf. There are no data at the mouth of Byrd Glacier, but the $50 \mathrm{MN} \mathrm{m}^{-2}$ contour some $200 \mathrm{~km}$ down-stream suggests very large values of $F$ at the point where Byrd Glacier becomes afloat. It also serves to illustrate the ability of the ice shelf to transmit stresses over very large distances. The low values of $F$ down-stream from ice stream $\mathrm{C}$ are revealing in that they support the suggestion that this ice stream is currently dormant (Thomas and others, in press). The progressive and well-ordered seaward decrease in $F$ shown in the channel to the grid west of Roosevelt Island exemplifies the idealized behavior of an ice shelf in a parallel channel, with a shear stress of $c \cdot 10^{5} \mathrm{~N} \mathrm{~m}^{-2}$ (one bar) between the ice shelf and its sides (Thomas, 1973[a|).

Down-stream from Crary Ice Rise there is a marked minimum in the values of $F$, and this is what we would expect as ice shelf forms in the lee of the ice rise. There is a similar minimum down-stream from the partially grounded peninsula between Roosevelt Island and Crary Ice Rise. Down-stream from both of these minima the $40 \mathrm{MN} \mathrm{m}^{-1}$ contours form lobes of high $F$. To some extent, these are probably caused by interaction between streams of ice that passed on each side of the up-stream grounded area. But the lobe of high $F$ down-stream from Crary Ice Rise may also be associated with localized partial grounding of the ice shelf (personal communication from K. Jezek 1980; Thomas and others, in press).

In order to illustrate the influence of the back pressure $P$ on ice-shelf behavior, we have

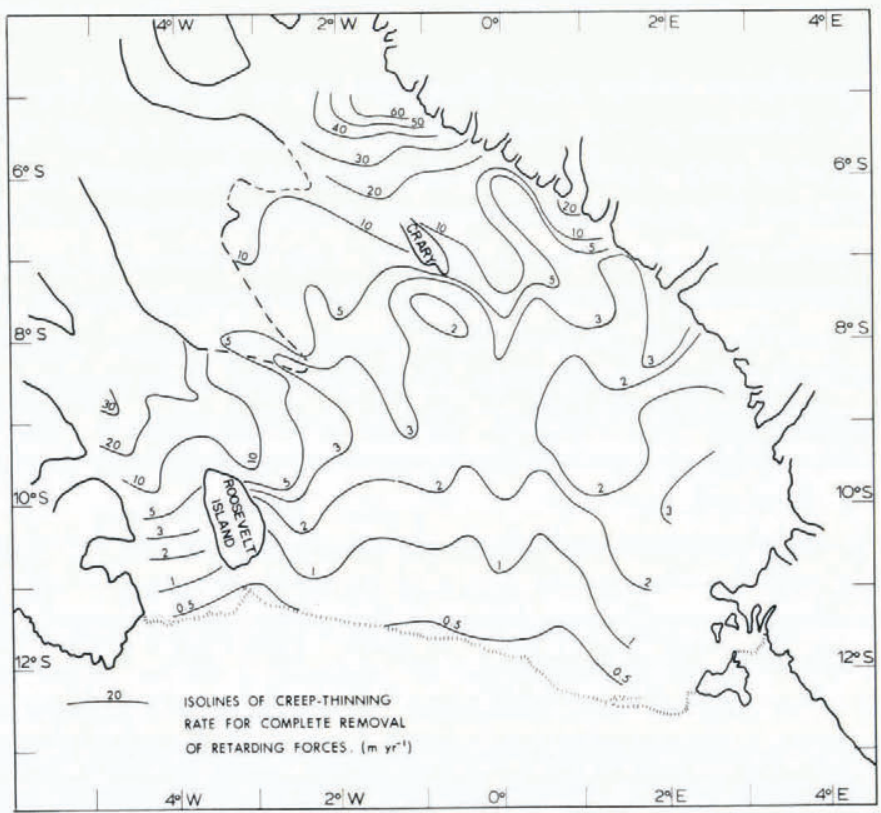

Fig. 9. The minimum rate in $m$ year ${ }^{-1}$ at which the Ross Ice Shelf would thin by creep if it was not embayed and it did not contain any ice rises. For this example, the ice shelf was allowed to spread in only one horizontal direction; for equal spreading in all directions the thinning rate would be almost $80 \%$ faster. The massive thinning rates in areas where the ice shelf is thickest would not be sustained; they would cause the ice shelf to trend towards a slab of uniform thickness with a corresponding reduction in the larger thinning rates. 
calculated horizontal strain-rates on a Ross Ice Shelf that has zero values of $P$ everywhere. Using the measured values of ice thickness (Bentley and others, 1979) we solved Equation (4) for an ice shelf free to creep in only one horizontal direction, and then calculated the creep-thinning rate as the product of creep rate and thickness. (For an ice shelf free to creep equally in all horizontal directions, the creep-thinning rate would be $c .80 \%$ faster.) The results are shown in Figure 9 where it can be seen that they are far larger than the observed values of c. $(0.5$ to 1) $\mathrm{m} \mathrm{year}^{-1}$. Figure 9 illustrates what would happen if we could instantaneously detach the Ross Ice Shelf from its margins and ice rises. Clearly, this is unlikely to happen, and even the loss of an ice rise (caused, for instance, by rising sea-level or warming climate) would take place over a long period. Up-stream creep-thinning rates would slowly increase, because $P$ in Equation (5) would be decreasing. However, the increase would be buffered by the effects, in Equation (5), of decreasing $H$. Thus, the major response to gradual ungrounding of an ice rise would be a small increase in up-stream thinning rate and a sustained thinning of the ice shelf. In general, this would be associated with a retreat of the grounding line. Finally, after the ice rise had completely disappeared, a new equilibrium ice-thickness configuration would be established for the ice shelf, with an associated equilibrium grounding line.

\section{Summary}

Particle-path calculations for several flow lines across the Ross Ice Shelf reveal areas where very old ice (up to 6000 years old) lies within $100 \mathrm{~m}$ of the surface. This ice was all deposited approximately at sea-level, and within a distance of a few tens of kilometers. Consequently, analysis of core samples in this area would be simplified by the absence of altitude- and geographical-position effects on the chemistry and isotopic composition of the snow. A glaciochemical transition in cores from the ice shelf has been associated with the $500 \mathrm{~m}$ contour level on the inland ice sheet. The depth to this transition compares well with our steady-state estimates for depth to ice from the $500 \mathrm{~m}$ contour. This suggests that the ice shelf and ice streams up-stream of the core holes have been approximately in steady state for the past 1500 to 2500 years. However, we stress that this conclusion cannot be applied to the entire ice shelf; in particular, detection of past changes in the activity of ice stream C and Byrd Glacier would require information from $200 \mathrm{~m}$ deep drill holes down-stream from these glaciers. The RIGGS data put us in a good position to determine where such drill holes should be sited to provide maximum information.

Comparison of calculated steady-state temperature/depth profiles with measured values at four stations indicate that bottom-melting rates are c. $0.7 \mathrm{~m}$ year ${ }^{-1}$ near the ice front, decreasing to $\pm 0.1 \mathrm{~m} \mathrm{year}^{-1}$ at $c .100 \mathrm{~km}$ inland: However, the data are so sparse that this can only be regarded as a very rough approximation.

Because the ice shelf has to push past its irregular sides, and around locally-grounded ice rises, it experiences a back pressure which reduces its creep-spreading rate. This back pressure increases from zero at the ice front to between one and two bars near the inland margins. Upstream of the ice rises, and at the mouths of glaciers and ice streams, the back pressure increases to three or four bars. The effects on the creep-thinning rate of removal of the back-pressure serve to highlight the importance of ice-shelf margins and, particularly, of ice rises in determining iceshelf thickness patterns. If these obstacles were removed, the creep-thinning rate would increase from its present range of ( 0.5 to 1$) \mathrm{m} \mathrm{year}^{-1}$ to ( 1 to 10$) \mathrm{m} \mathrm{year}^{-1}$ for most of the ice shelf, and up to $60 \mathrm{~m}$ year $^{-1}$ up-stream of the ice rises. 


\section{ACKNOWLEDGEMENTS}

This work was partially supported by a grant from the National Science Foundation. We are indebted to M. M. Herron and C. C. Langway, Jr for allowing us to use their unpublished data. and to M. M. Herron and R. A. Bindschadler for valuable discussion.

MS. received 3 July 1981 and in revised form 4 January 1982

\section{REFERENCES}

Barnes, P., and others. 1971. Friction and creep of polycrystalline ice, by P. Barnes, D. Tabor, and J. C. F. Walker. Proceedings of the Royal Society of London, Ser. A, Vol. 324, No. 1557, p. 127-55.

Bentley, C. R., and others. 1979. Ice-thickness patterns and the dynamics of the Ross Ice Shelf. Antarctica, by C. R. Bentley, J. W. Clough, K. C. Jezek, and S. Shabtaie. Journal of Glaciology, Vol. 24. No. 90, p. $287-94$.

Clausen, H. B., and others. 1979. Surface accumulation on Ross Ice Shelf, by H. B. Clausen, W. Dansgaard. J. O. Nielsen, and J. W. Clough. Antarctic Journal of the United States, Vol. 14, No. 5, p. 68-72.

Clough, J. W., and Hansen, B. L. 1979. The Ross Ice Shelf Project. Science, Vol. 203, No. 4379, p. $433-34$.

Crary, A. P. 1961. Glaciological studies at Little America Station, Antarctica, 1957 and 1958. IGY Glaciological Report Series (New York), No. 5.

Gow, A J. 1963. The inner structure of the Ross Ice Shelf at Little America V, Antarctica, as revealed by deep core drilling. Union Geodesique et Géophysique Internationale. Association Internationale d'Hydrologie Scientifique. Assemblee génerale de Berkeley, 19-8-31-8 1963. Commission des Neiges et des Glaces, p. 272-84. (Publication No. 61 de l'Association Internationale d'Hydrologie Scientifique.)

Herron, M. M., and Langway, C. C., jr. 1979. Dating of Ross Ice Shelf cores by chemical analysis. Journal of Glaciology, Vol. 24, No. 90 , p. 345-57.

MacAyeal, D. R. Unpublished. Transient temperature-depth profiles of the Ross Ice Shelf. |MSc. thesis. University of Maine at Orono, 1979.]

MacAyeal, D. R., and Thomas, R. H. 1979. Ross Ice Shelf temperatures support a history of ice-shelf thickening. Nature, Vol. 282, No. 5740, p. 703-05.

Robertson, J. D., and others. 1982. Sea bottom topography and crustal structure below the Ross Ice Shelf, Antarctica, by J. D. Robertson, C. R. Bentley, J. W. Clough, and L. L. Greischar. (In Craddock. C., ed. Antarctic geoscience. Symposium on Antarctic Geology and Geophysics, Madison, Wisconsin, U.S.A., August 22-27, 1977. Madison, University of Wisconsin Press, p. 1083-90.)

Rose, K. E. 1979. Characteristics of ice flow in Marie Byrd Land, Antarctica. Journal of Glaciology, Vol. 24. No. 90. p. $63-75$.

Thomas, R. H. 1973[a]. The creep of ice shelves: interpretation of observed behaviour. Journal of Glaciology. Vol. 12 , No. 64 , p. $55-70$.

Thomas, R. H. 1973[b]. The creep of ice shelves: theory. Journal of Glaciology, Vol. 12, No. 64, p. 45-53.

Thomas, R. H. 1973[c]. The dynamics of the Brunt Ice Shelf, Coats Land, Antarctica. British Antarctic Survey. Scientific Reports, No. 79

Thomas, R. H., and Bentley, C. R. 1978. The equilibrium state of the eastern half of the Ross Ice Shelf. Journal of Glaciology, Vol. 20, No. 84, p. 509-18.

Thomas, R. H., and others. In press. Glaciological studies on the Ross Ice Shelf, Antarctica, 1973-1978, by R. H. Thomas, D. R. MacAyeal, D. H. Eilers, and D. R. Gaylord. (In Hayes, D., and Bentley, C. R., ed. The Ross Ice Shelf: glaciology and geophysics. Washington, D.C., American Geophysical Union. (Antarctic Research Series, Vol. 40.))

Watroba, D. A. 1980. A chemical investigation of two ice cores taken from the Ross Ice Shelf, Antarctica. Geological Society of America. Abstracts with Programs, Vol. 12, No. 2, p. 88.

Weertman, J. 1957. Deformation of floating ice shelves. Journal of Glaciology, Vol. 3, No. 21, p. 38-42.

Zotikov, I. A., and others. 1980. Core drilling through the Ross Ice Shelf (Antarctica) confirmed basal freezing. by I. A. Zotikov, V. S. Zagorodnov, and Ju. V. Raikovsky [i.e. Yu. V. Raykovskiy|. Science, Vol. 207. No. 4438. p. $1463-65$. 